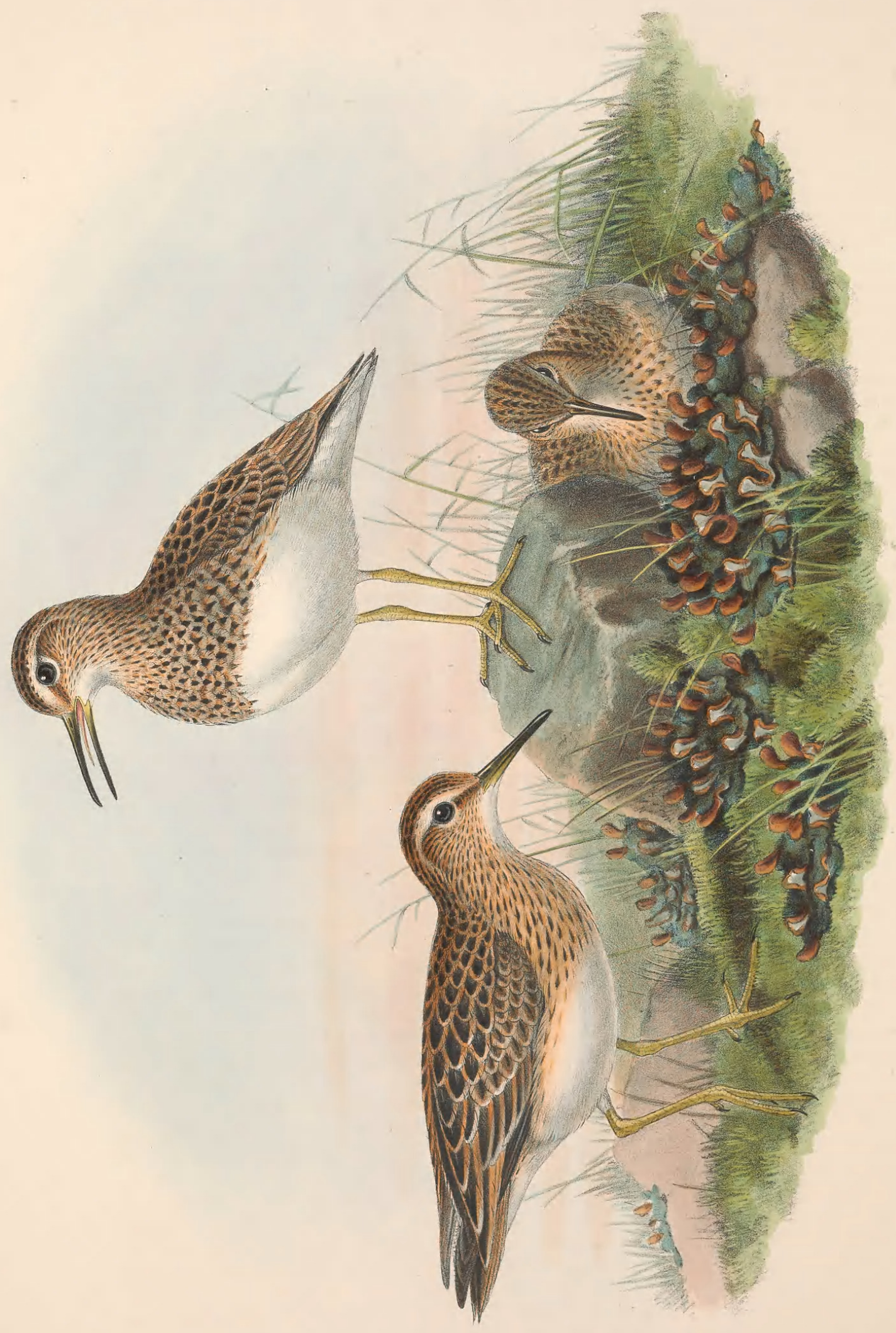

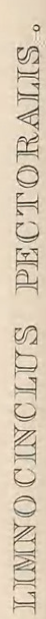




\title{
LIMNOCINCLUS PECTORALIS.
}

\author{
Pectoral Sandpiper.
}

Tringa maculata, Vieill. Nouv. Dict. d'Hist. Nat., tom. xxxiv. p. 465.

—_ pectoralis, Say, in Long's Exped., vol. i. p. 17 1.

campestris, Licht. Verz. der Doubl., p. 74.

Pelidna pectoralis, Bonap. Geog. and Comp. List of Birds of Eur. and N. Amer., p. 50.

maculata, Bonap. Tabl. des Echass., Compt. Rend. de l'Acad. Sci., tom. xliii., séances des 15 et 22 Sept. 1856.

Tringa (Actodromas) maculata, Baird, Cat. of N. Amer. Birds in Mus. Smiths. Inst., p. xlvii. no. 531.

Limnocinclus pectoralis, Gould, Handb. Birds of Aust., vol. ii. p. 254.

I норе my fellow-labourers in the field of ornithological science will coincide with me in retaining Say's specific name of pectoralis for this species of Sandpiper, in lieu of the prior but inappropriate one of maculatus assigned to it by Vieillot-more especially as it is commonly known, both in its native country (America) and in England, by the trivial name of Pectoral Sandpiper. In the second volume of my 'Handbook to the Birds of Australia,' I have instituted the genus Limnocinclus for the reception of this species and the old Tring a acuminata of Horsfield, better known as the T? australis of Jardine and Selby, a bird which so nearly resembles the Pectoral Sandpiper in its winter plumage that it is only by the discriminating eye of the ornithologist they can be distinguished the one from the other; in the summer plumage, however, they are very different.

Although several examples of the $L$. pectoralis have been killed in the British Islands, they can only be regarded as accidental visitors, individuals which have strayed over to this country, probably from America, where it ranges far and wide, from the tropics, through Mexico, Texas, and the United States, to Hudson's Bay: the Rev. H. B. Tristram has also killed it in Bermuda. The recorded notices of the Pectoral Sandpiper are, unfortunately, of no great interest; but such as they are they will be found below: in the meanwhile I would observe that I have at this moment before me several specimens in their full nuptial dress, and that there is another, finer still, in the collection at the British Museum. In this state I notice that the breast-feathers are much more lengthened than in winter, and have the spots with which they are adorned more sharply defined. These feathers the bird doubtless puffs out when endeavouring to attract the notice of the females; indeed we have reason to believe that the entire chest is then distended, after the manner of the Bustard and the domestic Pouter Pigeon, Mr. G. R. Gray having laid before the meeting of the Zoological Society of London, held on the 22nd of March, 1859, a drawing of this species made by the late Mr. Adams, Surgeon of H.M.S. 'Enterprise', representing the bird thus inflated, and remarked that, from the correctness of the other drawings made by the same gentleman, he had no doubt he had observed this singular phenomenon in the specimen from which the drawing was taken. "The drawing was more especially placed before the Members in the hopes of learning whether such a singularity of habits had been noticed before in this or any other of the Tringce." In winter the spots on the breast are not seen, their place being occupied by longitudinal striæ.

From a paper by the late J. D. Hoy, published in the 'Magazine of Natural History,' new series, vol. i. p. 115, we learn that the first occurrence of the Pectoral Sandpiper in England was "noticed, and a plate given, by Eyton in his Continuation of Bewick's 'Birds.' It was killed on the 17th of October, 1830, on the borders of Breydon Broad, an extensive sheet of water near Yarmouth, rather celebrated for the numerous rare birds which have, at different times, been observed and shot on its banks and waters. The person who killed it remarked that it was solitary, and its note was new to him, which induced him to shoot it. It proved, on dissection, to be a female." Dr. Edward Clarke informed Mr. Yarrell that another had been shot very near Hartlepool, in October 1841.

In a note from Mr. H. Stevenson, of Norwich, dated January 29, 1868, that gentleman says :- "I send you the dates of Mr. Gurney's and my Pectoral Sandpipers, as you requested. Mr. Gurney's was shot near Yarmouth, on the 30th of September, 1853; he had an opportunity of examining it in the flesh, and on dissection it proved to be a female and apparently a bird of the year; it was not fat, but in very fair condition. Its stomach contained some small seeds and the remains of a few insects, too much mutilated to be recognizable. Mine was shot at Caistor, near Yarmouth, on the 16th of September, 1865. It was brought in the flesh to one of our bird-stuffers, from whom I purchased it." Only last week, Dr. Lowe, of Lynn, sent me, to examine, not knowing what it was, another Pectoral Sandpiper,which had been netted in Terrington Marsh; it is now in the Lynn Museum. This also was a female and a young bird of the last year; the spots on the breast were very small, none of them transverse; a few new feathers, with rufous edgings, were making their appearance. This is the fourth authenticated Norfolk specimen. 
A Pectoral Sandpiper was shot near Filey, in the East Riding of Yorkshire; another at the Tees mouth, near Redcar; and a third in a grass-field, at Coatham, near the same place. It is also said to have been met with about Gwyllen Vale, near Falmouth ; and in June 1830 the late D. W. Mitchell, then of Penzance, but afterwards the well-known Secretary of the Zoological Society of London, sent to Mr. Yarrell " a coloured drawing and a fully detailed description, with measurements, of a specimen shot by himself on the 27 th of the previous month, while the bird was resting on some sea-weed within a few yards of the water on the rocky shore of Annet, one of the uninhabited islands of Scilly. On the following day another example was seen, but became so wild after an unsuccessful shot, that it flew off to another island, and escaped altogether. The close accordance of the specimen obtained with the description of Tringa pectoralis in the fourth part of Temminck's 'Manual' led Mr. Mitchell to a true conclusion as to the species and its novelty and interest in this country."

Having thus given all that is known to me respecting the Pectoral Sandpiper as seen in England, I proceed to furnish extracts from those who have had opportunities of observing it in its proper home and in other countries.

Mr. Nuttall says :- " This conspicuous species of Sandpiper, first detected by Mr. Say, is by no means uncommon in various parts of the United States, migrating north and perhaps west to breed, as they are common in the remote plains of the Mississippi, and retire at the approach of winter to the southern limits of the Union, being met with at this season also in the West Indies. They are killed in abundance on the shores of Cohasset, and other parts of Massachusett's Bay, and are brought in numbers to the markets of Boston, being very fat and well flaroured. They arrive in flocks, about the close of August, and continue there, as well as in New Jersey, till the month of September. In some instances, solitary individuals have been killed in the marshes of Charles River, in Cambridge, about the 22nd of July. While here, they feed on small coleoptera-larvæ, and the common green Ulva latissima, as well as on some species of Fucus or seaweed, on which they become fat. They utter a low plaintive whistle when started, very similar to that of other species. Like the Snipe, they seem fond of damp meadows and marshes; and solitary individuals are often surprised by the sportsman in the manner of that bird."

“This Sandpiper," says Audubon, " is more abundant in the neighbourhood of Boston than elsewhere. I have observed that the flight of the Pectoral Sandpiper resembles that of the Knot, and is firm, rapid, and well sustained. It skims rather low over the surface of the water or the land, and at times shoots high up into the air, propelling itself with double rapidity and in perfect silence. It runs with great agility, and probes the sand or wet earth, immersing its bill up to the base."

Mr. Edward Newton met with this bird occasionally in St. Croix, one of the West-India Islands, in 1858, after the 14th of September, and obtained some examples, but never saw more than two in company; and his brother, Mr. Alfred Newton, remarks that "specimens of this species differ remarkably in size, as is probably the case with many of the Tringine ; and it is possible that, in the present instance, it may be found that these differences in size are accompanied by a constant variation in plumage, and, perhaps, also in nesting-locality, so as to form races which should be always carefully distinguished from one another, as is the case with the smaller Dunlins of Europe and the Dunlin of America."

$\mathrm{Mr}$. Swinhoe observed the $\boldsymbol{L}$. pectoralis in great abundance in the marshes between Takoo and Pekin, in North China, during the month of August, and also procured it at Amoy.

Entire upper parts brownish black; all the feathers edged and tipped with ashy and brownish red ; rump and upper tail-coverts black; some of the outer feathers of the latter edged with white; line from the bill over the eye ashy white; throat, abdomen, under wing-coverts, axillary feathers, and under tail-coverts white; front of the breast and neck ashy white; all the feathers darker at the base, and with partially concealed or pointed spots of brownish black ; quills brownish black; shaft of the first primary white, of the others brown; secondaries tipped and edged with white; tertiaries edged with dull reddish yellow; bill and feet dark greenish black.

The Plate represents three specimens of this bird, of the natural size, the centre one being in the plumage of summer. 


\section{$2 \mathrm{BHL}$ Biodiversity Heritage Library}

Gould, John. 1873. "Pectoral Sandpiper, Limnocinclus pectoralis [PI. 67]." The birds of Great Britain 4, -. https://doi.org/10.5962/p.324023.

View This Item Online: https://www.biodiversitylibrary.org/item/221609

DOI: https://doi.org/10.5962/p.324023

Permalink: https://www.biodiversitylibrary.org/partpdf/324023

\section{Holding Institution}

Smithsonian Libraries

\section{Sponsored by}

Biodiversity Heritage Library

\section{Copyright \& Reuse}

Copyright Status: Public domain. The BHL considers that this work is no longer under copyright protection.

This document was created from content at the Biodiversity Heritage Library, the world's largest open access digital library for biodiversity literature and archives. Visit BHL at https://www.biodiversitylibrary.org. 